\title{
AOIR
}

Selected Papers of \#AoIR2020:

The 22nd Annual Conference of the

Association of Internet Researchers

Virtual Event / 13-16 Oct 2021

\section{DECLARATIONS OF INTERDEPENDENCE: HOW MEDIA LITERACY PRACTICES ARE DEVELOPED, NEGOTIATED, REJECTED, AND EXPLOITED ACROSS SOCIAL MEDIA PLATFORMS}

\author{
Elisha Lim \\ University of Toronto \\ Gina Marie Sipley \\ State University of New York (SUNY) at Nassau Community College \\ Ladan Siad \\ LANE Digital \\ Francesca Bolla Tripodi \\ University of North Carolina at Chapel Hill \\ Vincente Perez \\ University of California, Berkeley
}

\section{The Problems With Media Literacy: A Movement For Interdependence}

The primary goals of media literacy are laudable: active and critical thinking about the messages we receive and the messages we create (NAMLE, 2007, November). In practice, media literacy standardizes limited ways of knowing and normalizes built-in biases. Subsequently, its narrow emphasis on skill development, particularly the role of fact-checking, content creation, and independent research are all practices that can be exploited, oftentimes leading to the amplification of misinformation (Tripodi, 2018). Homogeneous media literacy also assumes that platforms are neutral - codifying a dominant, neoliberal, racist lens as a competency (Chun, 2011; Truman, 2019).

Suggested citation (APA): Lim, E., Sipley, G.M., Siad, L., Tripodi, F. B., Perez, V.. (2021, October). Declarations of interdependence: How media literacy practices are developed, negotiated, rejected, and exploited across platforms. Panel presented at AolR 2021: The 22nd Annual Conference of the Association of Internet Researchers. Virtual event: AolR. Retrieved from http://spir.aoir.org. 
Social media literacy assumes the norms of proprietary algorithms, arming users with the skills determined by Silicon Valley's corporate, individualist, white supremacist values (Marwick, 2013; Bucher, 2018; Sweeney, 2016). Contemporary high school curricula teaches students to ably brand and promote themselves, enshrining neoliberal ideologies of self-responsibilized entrepreneurship (“Ontario", 2019). Adept meme creators are rewarded for racial appropriation and pathologized, fungible performances of Blackness (Brock, 2012). Vanity metrics foster reputation anxiety in social media's 'success theatre' (Rogers, 2018). Personal data protection is an arguably futile lesson in privacy that preaches paranoid gated communities (Chun, 2016). Fascist media pundits easily exploit conservative media literacy practice of "doing your own research" to naturalize misinformation. Social media literacy standards teach an iteration of what Black feminist Hortense Spillers' (1987) calls "American grammar" - an ongoing, white supremacist symbolic value system "grounded in the originating metaphors of captivity and mutilation" (Spillers, 1987, p. 68).

What are the implicitly raced, classed norms of reading "correctly"? What are mundane everyday emancipatory reading practices? What alternative literacy practices do users deploy to reject these individualistic, racist standards, and forge their own interdependence? What does interpretive media literacy look like?

This panel offers a portrait of what's missing in media literacy and explores visions of interdependent practices that offer alternative methods of active and critical thinking about the messages we receive and the messages we create. Seeking to illuminate the range of platform based literacy practices employed by different demographics, this panel will discuss how alternative literacy practices are developed, exploited, or subversively spread.

\section{Research Themes And Questions}

Our papers are in dialogue with the following themes:

- The interdependent and relational nature of literacy practices

- "Private data" and the emphasis on individualistic property rights

- Anti-Blackness within "proficient" corporate social media platform use

- The neoliberal nature of algorithmic popularity principles

- The partisan manipulation of platform affordances

- The normalization of literacy and engagement based on platform objectives, across Facebook, Twitter, Instagram and Youtube

This panel brings together designers, graduate students and early to mid-career scholars from across the United States and Canada to explore the questions:

- How are media literacy practices culturally situated?

- How is refusal a type of literacy?

- What are the colonial capitalist legacies of dominant media literacy?

- How do new, independent social media literacies foster interdependence?

- What new forms of independence are emerging on the internet and how might they challenge preexisting power relationships and struggles? 
- In what ways are media literacy practices exploited for political gain?

\section{The Papers: Alternative literacy practices}

The first paper looks at algorithmic incentives to read Facebook and Instagram "right" to the detriment of collective organizing. Using a comparative genealogical method, this paper locates \#DefundThePolice as a new iteration of historical civil rights tactics: radical algorithmic literacy that learns to read the monetary incentives of the platform and circumvent its trap, rejecting individual self-promotion in the place of collective bargaining power.

The second paper's key argument is that media literacy is used inaccurately because it focuses on skill adoption rather than meaning-making. Based on over 30 hours of interviews with middle aged and older adult Facebook users in neighbourhood groups, this paper explores 'lurker' literacies as a form of deep receptive reading and participatory restraint that avoids being captured by vanity metrics. In order to protect their privacy from Facebook and from their neighbours, these users share content discovered on Facebook offline, in order to build sustainable community interdependence.

In the third paper, marginalized groups defy media literacy standards in favour of "play." Based on workshops and skillshares designed by and for communities of colour in Toronto and New York, this paper argues that existing marginalized data reclamation projects are grounded in rhetorics of data "power" and "threat" that reify cybersecurity and policing. Instead, this paper reports back from workshops that explore playful data practices grounded in Black queer feminist tactics like the glitch (Russell, 2012), the parasite (Jordan, 1969), the residency (Ferguson, 2012) and the hack (Johnson, 2018).

The fourth paper looks at Conservative right wing ecosystems driven by social media's individualistic tools. Using qualitative content analysis and scraped metadata, the paper looks at how the manipulation of one technological affordance (for example edits on Wikipedia, hash-tagging on Twitter, and YouTube metadata) are used to game search engine optimization. By calling on conservatives to "do their own research" this mechanism exploits the power-structures embedded in media literacy practices.

The fifth paper looks at Black Twitter users who refuse to read the platform "right" in a racist antiblack digital civic sphere. The paper focuses on "anagrammatical" praxis (Sharpe, 2016) wherein Black Twitter users engage in hacking virality, covert publicity, and Black vernacular signyfyin' to create a multifaceted and adaptive strategy of making sense of the incomprehensible nature of antiblackness.

\section{References}

Brock, A. (2012). From the blackhand side: Twitter as a cultural conversation. Journal of Broadcasting \& Electronic Media, 56(4), 529-549. 
Chun, W. H. K. (2011). Race and/as technology, or how to do things to race. In L. Nakamura and P. Chow-white (Eds.) Race after the internet. pp. 38-60. Routledge.

Ferguson, R. (2012). The reorder of things. University of Minnesota Press.

Johnson, J.M. (2018). Markup bodies: Black [life] studies and slavery [death] studies at the digital crossroads." Social Text. 36. 57-79.

Jordan, J. (1969). Black studies: Bringing back the person. Moving Towards Home: Political Essays. Beacon Press.

Marwick, A. E. (2013). Status update: Celebrity, publicity, and branding in the social media age. Yale University Press.

National Association for Media Literacy Education. (2007). Core principles of media literacy education in the United States.

https://namle.net/publications/core-principles/

"Ontario Curriculum: Career Studies, Grade 10, Open, The" (2019)

http://www.edu.gov.on.ca/eng/curriculum/secondary/career-studies-grade10.pdf

Rogers, R. (2018). Digital traces in context otherwise engaged: Social media from vanity metrics to critical analytics. International Journal of Communication, 12, 450-472. https://dare.uva.nl/search?identifier=e7a7c11b-b199-4d7c-a9cb-fdf1dd74d493

Russell, L. (2013). Glitch feminism and the genesis of glitch body politic. Rhizome. Mar 12. https://rhizome.org/editorial/2013/mar/12/glitch-body-politic/

Sharpe, C. (2016). In the wake: On blackness and being. Duke University Press.

Spillers, H. J. (1987). Mama's baby, papa's maybe: An American grammar book. Diacritics, 17(2), 65-81.

Sweeney, M. E. (2016). "The intersectional interface." Eds. S.U. Noble and B.M. Tynes The intersectional internet. pp. 215-228. Peter Lang. 


\title{
AOIR
}

Selected Papers of \#AoIR2021:

The 22nd Annual Conference of the

Association of Internet Researchers

Philadelphia, PA, USA / 13-16 Oct 2021

\section{\#DEFUNDTHEPOLICE - BLACK LIVES MATTER: RADICAL ALGORITHMIC LITERACY}

\author{
Elisha Lim \\ University of Toronto

\section{Harnessing Algorithms for Collective Welfare}

Social media undermines civil rights efforts by rewarding self-promotion and individual advantage that disincentivizes interdependence. This paper locates the movement \#DefundThePolice - Black Lives Matter within a genealogy of civil rights tactics. The hashtag movement counteracts neoliberal platform agendas by deploying algorithms instead for unified collective bargaining. Black Lives Matter's (BLM) strategy joins a legacy of civil rights actions that map out cooperative interdependence even within neoliberal individualistic exceptionalism - modelling radical algorithmic literacy to reroute algorithms on behalf of the equitable redistribution of resources.

\section{Method}

\#DefundThePolice came as a shock to critics who envisioned an attack on reliable state institutions in favour of lawless anarchy. Fox News quoted Crime Stoppers of Houston: "We're disrespecting the thousands of officers who serve with their heart and mind with no regard for race, creed, or color, and we're disrespecting the thousands of officers who have given their lives in exchange for others" (McKay 2020). Conservative backlash against \#DefundThePolice launched a rhetoric of rational, well-intentioned, neutral, hardworking state police institutions threatened by irrational demands.

A genealogy is a counter-historical technique that challenges "rational" discourse by exposing long-standing "battles between knowledges - in the plural" (Foucault \& Ewald, 2003). In fact, \#DefundThePolice is not an irrational break from reality, but a continuation of a 50 year wrestle between interdependent civil rights solidarity, and Suggested citation (APA): Lim, E. \#Defundthepolice - Black Lives Matter: Radical Algorithmic Literacy. Panel presented at AolR 2021: The 22nd Annual Conference of the Association of Internet Researchers. Virtual event: AolR. Retrieved from http://spir.aoir.org. 
pro-business individualist exceptionalism. I use genealogy to demonstrate how \#DefundThePolice, and its algorithmic strategies, represents an enduring interdependent socio-economic knowledge that consistently challenges dominant individualism.

\section{From Identity Politics to Identity Economics}

On social media platforms like Facebook, Instagram and Twitter, algorithms reward individuals who conform to its norms with visibility, status and influence (Bucher 2018). Users scrutinize their personal clout in an unconscious absorption of the algorithms' economic ideals (Marwick, 2014). New norms of personal brand management and self-promotion emphasize the importance of speculative personal assets and individual human capital (Browne, 2012).

In this arena, marginalized users are incentivized to build and optimize their brands around disenfranchisement, according to commercial objectives - a trend I have referred to as "identity economics." The commodification of personal identity yields vulgar public endorsements, like the much-criticized hollow corporate solidarity statements with Black Lives Matter after the 2020 murder of George Floyd. However more insidiously, these economic principles compromise grassroots organizing. Content curated by popularity principles generates hierarchies within marginalized communities manifest in callout culture, authenticity inquests, and legitimacy contests. As marginalized actors are incentivized to build brands around their personal politics, identity becomes an individual property entitlement to patrol and protect. This is not a sign of personal failing, but the neoliberal drive to privatize intimate life.

\section{Evolving Civil Rights Tactics}

Even before the advent of social media, critical race scholars articulated how neoliberal efforts sabotaged civil rights movements by tempting activists to profiteer off of their identity politics (Lorde, 2012; Tadiar, 2016; Ferguson 2012). 1960s U.S. civil rights movements like Black Power and third world feminism called for marginalized communities to reclaim social differences for collective empowerment (Lorde, 2012). But neoliberal activism began eroding grassroots organizing in the 1970 s by alluring minority actors into stable careers in related fields, like Women's Studies or Ethnic Studies, which assimilated activists to accept and gradually enforce the normative protocols of state and capital institutions (Duggan, 2003; Ferguson, 2012). In this sense, identity-based self-branding on social media is a continuation of a historic capitalist tactic that strategically affirms difference to advance its agenda (Lowe, 2015; Ahmad 2015). 
As neoliberal strategies weakened grassroots civil rights movements in the 1970s, centrist civil rights elements emerged as single-issue centrist lobby organizations aligned with market interests, shoring up inclusion for the privileged few, like "color-blind" anti-affirmative action racial politics, conservative-libertarian "equality feminism," and LGBT "normality". These activists sought institutional assimilation, fundraising opportunities and survival, and chose to adopt corporate decision making models and rhetorical commitments to diversity, including the limits and false promises of the "equality" of liberal reform divorced from material life, class politics, and any critique of global capitalism (Duggan, 2003; Browne, 2015; Fernandes 2017).

Today social media accelerates this assimilation. Marginalized activists are incentivized to optimize their identities as unique value-added propositions within evacuated single-issue representational diversity optics, disarticulated from class analysis, deployed to shore up the authority and social capital of the speaker in a legacy of dehumanizing, liberal property entitlement. In this way pro-business individualism discourages collective bargaining - for the secure jobs, fair wages, rent freezes, lower tuition, universal healthcare and other resources that marginalized communities need (Duggan, 2003; Browne, 2015; Fernandes 2017).

\section{Radical Algorithmic Literacy}

Within 3 months, the BLM hashtag \#Defundthepolice spurred the reallocation of billions of dollars in police funding: $\$ 150$ million transferred from police departments to health care, accessible employment and peace centers, food access, abortion access, mental health support and violence prevention programs (Coronado, 2020). This wasn't an overnight battlecry, it took years of planning. Since 2015, BLM has developed mutually dependent relationship-building through freedom schools, skillshares and demands like defunding the police, which began during the 2018 movement Reclaim the Block (Collins, 2018).

On BLM's website, \#DefundThePolice includes comprehensive demands to de-invest in policing and re-invest in education, counselling, mental health, restorative services, community led harm reduction, healthcare, housing (Scales, 2020). But even if social media users only saw, and re-tweeted \#DefundThePolice, they were thinking about economic matters, class issues, and material change. BLM's hashtag defies popularity metrics because it is more than rhetoric - it is an economic demand that harnesses popularity algorithms while refusing mere representational optics. \#DefundThePolice intervenes in the distracting individualistic exceptionalism of neoliberal social media to restore the original 1960s civil rights mandate of class war and economic redistribution.

\section{References}


Ahmad, A. (2015) "A note on call-out culture." Briarpatch Magazine.

Bucher, T. (2018) If... Then Algorithmic Power and Politics Oxford University Press

Collins, J. (2018) "Mpls. council moves to shift \$1.1 million from police department." MPRNews. December 1.

https://www.mprnews.org/story/2018/11/30/mp/s-budget-amendment-removes-million-do Ilars-police.

Coronado, A. (2020) "Austin cuts police budget by $1 / 3$ amid national 'defund' push." The Washington Post. August 13.

https://www.washingtonpost.com/health/austin-cuts-police-budget-by-13-amid-nationaldefund-push/2020/08/13/57845be4-ddab-11ea-b4f1-25b762cdbbf4_story.html

Duggan, L. (2003) The twilight of equality? Beacon Press.

Ferguson, R. A. (2012). The reorder of things: The university and its pedagogies of minority difference. University of Minnesota Press.

Fernandes, S. (2017). Curated stories: The uses and misuses of storytelling. Oxford University Press.

Foucault, M., \& Ewald, F. (2003). " Society Must Be Defended": Lectures at the Collège de France, 1975-1976 (Vol. 1). Macmillan.

Lorde, A. (2012). Sister outsider: Essays and speeches. Crossing Press.

Lowe, L. (2015) The Intimacies of four continents. Duke University Press.

Marwick, A. E. (2013) Status update: Celebrity, publicity, and branding in the social media age. Yale University Press.

McKay, H. (2020) "Defund or dismantle the police? What it could mean." Fox News. June 9

https://www.foxnews.com/us/what-would-it-look-like-to-defund-or-dismantle-the-police

Noble, S. U. (2018). Algorithms of oppression: How search engines reinforce racism. NYU Press.

Scales, K. (2020). "What defunding the police really means." blacklivesmatter.com. July 6. https://blacklivesmatter.com/what-defunding-the-police-really-means/

Spillers, H. J. (2003). Black, white, and in color: Essays on American literature and culture. University of Chicago Press.

Tadiar X. M. N. (2016) Ground zero. GLQ: A journal of lesbian and gay Studies, Volume 22, Number 2. p. 173-181 


\title{
AOIR
}

Selected Papers of \#AoIR2020:

The 22nd Annual Conference of the

Association of Internet Researchers

Philadelphia, PA, USA / 13-16 Oct 2021

\section{RECEPTIVE READING AND PARTICIPATORY RESTRAINT IN FACEBOOK GROUPS}

\author{
Gina Marie Sipley \\ State University of New York (SUNY) Nassau Community College

\section{Resisting Vanity Metrics}

Facebook is an aging platform whose most devoted users are older adults (Pew Research, 2019). As Facebook's privacy features have become more complicated to navigate and as Facebook's surveillance practices have become more widely recognized by mainstream culture, middle aged to older adult Facebook users have begun to assert their independence from the site. This independence is facilitated through a conscious resistance of vanity metrics. Vanity metrics refers to "the measurement and display of how well one is doing in the 'success theatre' of social media" (Rogers, 2018, p. 450). Objects of vanity metrics can include any data that indicates influence (Rao et al., 2016). One of the few things a social media user can control is the trace their digital reading experience leaves behind. For older adults, the choice to engage in lurker literacies, reading practices that cannot be captured by vanity metrics (Sipley, 2020), affords a degree of autonomy and protection from context collapse and mediated lurking (Child and Starcher, 2016) by their personal connections and members of their community.

Although older adult Facebook users are aware that their continued presence on Facebook means they are still under corporate surveillance, they also know that by reading without engaging in vanity metrics and leaving a public record of interaction, they are defying corporate objectives to enhance interactivity among users. Where the term lurking carries negative connotations, the reasons why one chooses to lurk are not always nefarious. Lurking and active participation are not binary practices. Lurking is a regular, participatory act that all social media users engage in depending on context 
(Nonnecke \& Preece, 2001). When Facebook users choose to resist vanity metrics, they do so for reasons reminiscent of what Rosenblatt (1969) refers to as the continuum of efferent and aesthetic reading experience. My qualitative research explores two concepts, receptive reading and participatory restraint (Sipley, 2021), media literacy practices that older adult users engage in while lurking in neighborhood Facebook groups as a way to build interdependence among members of the local offline communities.

Receptive reading occurs when a social media user wants to closely, and anonymously, read a commenting thread with the express purpose of understanding a divergent point of view. This creates the opportunity for material interdependence among older adult Facebook group users who seek to maintain and strengthen relationships with members of their community despite neoliberal corporate desire for maximized digital interaction, regardless of the social costs.

Participatory restraint is a strategic literacy practice whereby a social media user will purposefully not respond to an inflammatory post because they want to limit the "oxygen of amplification" (Phillips, 2018) and contain the story. These efforts are sometimes taken individually and are sometimes collectively decided by group members using non-Facebook communication to purposefully not comment, like, or share their dissent via Facebook vanity metrics.

\section{Methodology}

My research relies on data from interviews and qualitative content analysis of Facebook group features. Over 30 hours of interviews were conducted with 16 American Facebook users during the summer and fall of 2020 and participants discussed their reading practices of neighborhood Facebook group content in relation to current events such as Black Lives Matter, the 2020 United States presidential election, COVID-19, and vaccination. Qualitative content analysis focused on the Facebook features participants discussed as relevant factors in their decision-making process: what to read, when to resist vanity metrics, and why.

\section{Findings}

Participants revealed that they were most likely to engage in receptive reading when they were reading the comments of someone they knew, both in the group and in real life, who was discussing a controversial topic. The decision to receptively read was rooted in a combination of desires: curiosity about why the poster held these beliefs, eagerness to maintain a friendly relationship with the poster, fear of confrontation with other members of the Facebook group, preservation of business or financial interests, and fear of professional reprimand. The valuable contribution of receptive readers in neighborhood groups is the way that this literacy practice forges material interdependence among members of the same community. Some of the ways that participants engaged in material interdependence was by supporting local businesses in response to COVID-19 after reading first-hand accounts of restaurant workers, 
acknowledging white privilege from reading fact sheets posted by neighbors about systemic racism, calling or meeting with posters in real life to further discuss differences of opinion on the election on COVID-19.

Participants explained that they were most likely to engage in participatory restraint when they felt that the material stakes of an inflammatory post going viral were too high. For example, participants eager for their local school district to safely reopen schools during COVID-19 were outraged by a post arguing that community members should not contribute to a fundraiser to upgrade the ventilation system in the schools. The original poster was concerned about how the increased cost of school reopenings in a pandemic would impact local taxes. By strategically not commenting on this post, participants allowed a vocal minority of Facebook neighborhood group participants to argue among themselves without giving them the tools to broadcast their ideas to a larger network. In the past this vocal minority has had their anti-school-tax posts amplified by community members engaging in vigorous circuitous debate. The fundraising campaign was successful and schools K-8 reopened fulltime in part because participatory restraint restricted the visibility of the anti-school-tax post. Participatory restraint relies on a sophisticated understanding of the effects of amplification and requires users to weigh the efficacy of visible dissent via vanity metrics against the collective containment of the story through the resistance of vanity metrics.

\section{References}

Child, J. T., Pearson, J. C., \& Petronio, S. (2009). Blogging, communication, and privacy management: development of the blogging privacy management measure. Journal of the American Society for Information Science and Technology, 60, 2079-2094. http://dx.doi.org/10.1002/asi.21122.

Child, J. T., \& Starcher, S. C. (2016). Fuzzy Facebook privacy boundaries: Exploring mediated lurking, vague-booking, and Facebook privacy management. Computers in Human Behavior, 54, 483-490. doi:10.1016/j.chb.2015.08.035

Nonnecke, B., \& Preece, J. (2001). Why lurkers lurk. In Paper presented at the Americas conference on information systems conference, Boston. http://www.cis.uoguelph.ca/ nonnecke/research/whylurk.pdf

Pew Research (2019) Share of U.S. adults using social media, including Facebook, is mostly unchanged.

https://www.pewresearch.org/fact-tank/2019/04/10/share-of-u-s-adults-using-social-med ia-including-facebook-is-mostly-unchanged-since-2018/

Phillips, W. (2018). The oxygen of amplification: Better practices for reporting on extremists, antagonists, and manipulators. Data and Society. https://datasociety.net/wp-content/uploads/2018/05/1 PART_1 Oxygen_of_Amplificatio $\underline{\text { n DS.pdf }}$ 
Rogers, R. (2018). Digital traces in context otherwise engaged: Social media from vanity metrics to critical analytics. International Journal of Communication, 12, 450-472. https://dare.uva.nl/search?identifier=e7a7c11b-b199-4d7c-a9cb-fdf1dd74d493.

Rosenblatt, L. M. (1969). Towards a Transactional Theory of Reading. Journal of Reading Behavior, 1(1), 31-49. https://doi.org/10.1080/10862969609546838

Sipley, G. M. (2020). 'Lurker' literacies: Living in/through neighborhood Facebook groups. AolR Selected Papers of Internet Research, 2020.

https://doi.org/10.5210/spir.v2020i0.11331 


\title{
AOR
}

Selected Papers of \#AoIR2020:

The 22nd Annual Conference of the

Association of Internet Researchers

Philadelphia, PA, USA / 13-16 Oct 2021

\section{INHUMAN LITERACIES: PLAY AS AFFECTIVE REFUSAL}

\author{
Ladan Mohamed Siad \\ Lane Digital Research Studio
}

"Play Over Paranoia" is a workshop that puts a twist on recent efforts to empower data reclamation by marginalized communities. The workshop is run by and for marginalized communities in Toronto and New York, and is hosted by four QTBIPOC digital designers from the Lane Digital Research Studio: Ladan Mohamed, Aljumaine Gayle, Nabil Vega and E.L Guerro.

This paper will explain how "Play Over Paranoia" differs from recent data reclamation projects, by refusing cybersecurity's grammar of "power" in favour of play. This work uses Sarah Truman's (2019) framing of literacies: that "literacy and education more broadly reflect and reproduce world views and communicative practices rooted in the western epistemological conceptualization of what Sylvia Wynter calls 'Man."' This paper couches "play" in Black queer feminist theories: the glitch (Russell, 2012), the parasite (Jordan, 1969), the residency (Ferguson, 2012) and the hack (Johnson 2018).

\section{Waywardness}

"Play Over Paranoia" builds on, and diverges from, data reclamation projects such as "Our Data Bodies" (ODB) and the Oxford Internet Institute's (OII) 2020 project titled "Reconfigure: Feminist Action Research in Cybersecurity." ODB's Digital Defense Playbook offers workshops for participants to reclaim their data through "Community Power Tools" and to identify collective alternatives to unjust data collection - flipping the script on "defense" and restoring "power" to marginalized users (Digital Defense, p. 71). Similarly, "Reconfigure: Feminist Action Research in Cybersecurity" teaches communities to identify their own empowered form of "threat modeling" ("Reconfigure"), defined as a method to systematically model "assets" (i.e what you want to protect), "threats" (i.e. how you could be attacked \& potential attackers), and "mitigations" (what you can do to defend yourself) ("Reconfigure," p17).

Suggested citation (APA): Siad, L. Inhuman literacies: play as affective refusal. Panel presented at AoIR 2021: The 22nd Annual Conference of the Association of Internet Researchers. Virtual event: AolR. Retrieved from http://spir.aoir.org. 
These data reclamation projects use rhetorics of "power," "defense" and "threat modeling" that draw on the computer systems theories of cybersecurity practices developed in the 1990s. However security rhetorics justify policing and incarceration, which is a continuation of chattel slavery where Blackness was made into object/property. As Black theorist Rinaldo Walcott argues, "policing is dependent upon the faith and enduring belief that something wrong might happen to us" $(2021,37)$. This paper rejects the grammar of cybersecurity that indexes humanized assets and relies on the logics of policing for protection from a perceived non-human "threat."

Instead, this workshop builds on Jessica Marie Johnson's (2018) call for Black freedom to "hack their way into the system (modernity, science, the West), take root, and live where they were "never meant to survive,"' as well as what June Jordan (1969) and Roderick Ferguson's (2012) call Black organizing as a parasite. While Ferguson uses Jordan's concept of the parasite in the context of a critique of academia, his call is equally relevant to the internet. Ferguson notes how "black critical formations [are] a life intent on using the academy for other forms of learning and subjectivization that the institution never intended. Like a parasite, Black Studies would produce critical formations in numbers that the host would never imagine or suspect. Black studies, in this sense, would exploit the academy for sustenance, residency, and dispersal, imagining ways to be more in the academy than of it" (Ferguson, 2012; 108). We also build on Legacy Russell's Glitch Feminism (2012): "The first step to subverting a system is accepting that that system will remain in place; that said, the glitch says fuck your systems! Your delineations! Your determination was imposed upon our physicality!" Also of import to our work is Sylvia Wynter's writing on autopoiesis- that is to say, the processes through which human beings are constituted as homo narrans through language and storytelling. After Russell's invocation of the glitch, Jonhson's work around the hack, and Ferguson/Jordan's parasite, we create interruptions into current discourses regarding data-driven technologies, towards new conceptions of data justice that do not hinge on cybersecurity's anti-Black grammar.

Like Walcott $(2021 ; 27)$ we reject the thingification of Blackness that is now occurring on the internet, and how the extractive logics that animate the creation and use of data are produced by and sustain the matrix of domination (Collins, 1990; Design Justice Network 2019): "I'm suggesting that [Black people's] long history of thingification and how we have resisted it stands as a political and intellectual blueprint for how we can transform all of human life."

Instead, we play, glitch, hack and refuse. We seek to practice a Data Justice that interrupts what we call the "extractive logic" of cybersecurity- that is to say, the logic of pulling relations out from bodies and lands into data directed towards thingification. Gestures of play, refusal and attention to affect can subvert dominant uses of surveillance and commodification of our online data.

\section{Method}

The "Play Over Paranoia" design justice workshops took place three times between 2019 and 2020 by invitation: at Eyebeam, the Museum of Contemporary Art Toronto, and Xpace Gallery. The workshops were structured around three themes that highlight 
the participants' own situated, collective knowledge and intuitive, interdependent literacy, in contrast to discourses of digital literacy version of highly individualized cybersecurity. This workshop gives participants a practical understanding of their digital relationships and presence, to challenge cybersecurity's narrative of domination and paranoia. The workshop is structured as follows:

\section{Techno Jargon}

Using interactive, tactile and non-digital approaches, participants are guided in a physical, full-body activity that re-appropriates google data traces, and other tools, to co-create their data bodies/profiles/assemblages.

\section{What data privacy really says about you}

Participants are led in a discussion to unpack and challenge the amorphous grammar of online cybersecurity, watching and tracking and its historic roots in systemic, carceral surveillance structures.

3. Why we should move away from individualization of data privacy A skillshare invites participants to brainstorm modes of safety enabled by collectivity, mutual aid networks, online communities, communal venting spaces, and other interdependent possibilities.

\section{Findings}

Play and practices of refusal demonstrate how oppressive power structures and surveillance "AFK" are not radically different from surveillance happening online. Upcoming workshops will incorporate the work of Data Healing, Cyber Doulas, hacking, Legacy Russell's 2012 concept of AFK, and Divest from Instagram (a call for queer Black and Brown creators to leave a platform that profits from their creativity).

\section{References}

Ferguson, R. (2012) The Reorder of things. University of Minnesota Press.

Jordan, J. (1969). Black Studies: Bringing Back the Person. Moving Towards Home: Political Essays.

Johnson, J.M. (2018) "Markup Bodies: Black [Life] Studies and Slavery [Death] Studies at the Digital Crossroads." Social Text 1 December 2018; 36 (4 (137)): 57-79.

Reconfigure: Feminist Action Research in Cybersecurity', Oxford Internet Institute, $2021<$ https://www.oii.ox.ac.uk/reconfigure-report-2020

Russell, L. (2013). Elsewhere, After the Flood: Glitch Feminism and the Genesis of Glitch Body Politic. Rhizome. Mar 12.

https://rhizome.org/editorial/2013/mar/12/glitch-body-politic/

Truman, S. E. (2019). Inhuman literacies and affective refusals: Thinking with Sylvia Wynter and Secondary School English. Curriculum Inquiry, Special Issue on 


\section{Sylvia Wynter}

Walcott, R. (2021) On Property. Biblioasis. 


\title{
AOIR
}

Selected Papers of \#AolR2021:

The 22nd Annual Conference of the

Association of Internet Researchers

Philadelphia, PA, USA / 13-16 Oct 2021

\section{Media Literacy + Tech Affordances = Media Manipulation}

\author{
Francesca Bolla Tripodi \\ University of North Carolina - Chapel Hill
}

\section{Producers' exploit media literacy and tech affordances to spread misinformation}

Information-seekers engage in a distinct set of media practices tied to the way they see the world, yet much work on combating misinformation is structured around a static understanding of digital media literacy. Manipulators understand that literacy is contextually dependent but also utilize platforms via tech affordances unanticipated by designers/programmers (Bucher, 2012; Tripodi, 2017). To that end, this paper explores how literacy practices and technological affordances are exploited by those who have the ability and knowhow that others do not. Drawing on three case studies, this paper explains how the manipulation of one technological affordance (e.g. edits on Wikipedia, hash-tagging on Twitter, and YouTube metadata) are used in conjunction with the conservative media literacy practice of "doing your own research." Unpacking "platform specificities" plays an important role in the empirical analysis of media manipulation (Bucher and Helmond, 2017). By seeing the role affordances play in media manipulation campaigns, this paper sheds light on how media literacy is an exploitable process.

\section{Conservative media literacy}

Previous studies have used big data analytics to understand the science of fake news, providing insights into how misinformation, disinformation, and malinformation impacts voter turnout and decision-making (Lazer et. al., 2018, Wardle and Derakhshan, 2017). Other research also demonstrates that the extent to which audiences believe and share problematic content is connected to the institutional and epistemological nature of knowledge production (Anderson, 2020; Benkler et. al., 2018; Marwick, 2018; Tripodi,

Suggested citation (APA): Tripodi, Francesca Bolla. Media Literacy + Tech Affordances $=$ Media Manipulation. Panel presented at AolR 2021: The 22nd Annual Conference of the Association of Internet Researchers. Virtual event: AolR. Retrieved from http://spir.aoir.org. 
2018). Combining Stuart Hall's theory of encoding/decoding to media manipulation campaigns can provide more contextual understanding of how media literacy is also dominant, negotiated, or oppositional.

This paper explains how conservatism as a set of media practices is connected to the spread of misinformation. Contrary to the widely held belief that Trump supporters were tricked into voting for him because of "fake news," Tripodi (2018) demonstrates that conservatives are avid news consumers driven by a responsibility to dig in to original documents and dissect truth claims as individuals. Rather than rely on experts for interpretation, conservatives reject elitist interpretations in favor of "doing their own research" (Tripodi, 2018). By understanding how conservatives verify information (i.e. Google) that aligns with their central beliefs (e.g. media is bias), these cases demonstrate that the RWME effectively understands the interdependence between social and technical systems (Bijker, 1995).

\section{Google Searches and Data Voids}

For nearly a decade, Americans writ large have trusted Google more than traditional news outlets (Schultheiss and Lewandowski, 2021; Vaidhyanathan, 2012). But the process of search also implies trust in the search engine itself, that Google, Bing, or DuckDuckGo will return relevant (i.e., useful and accurate) information (Haider and Sundin, 2019). As such, the way in which search engines order information matters. A page's "rank" has less to do with credibility and more to do with what Google refers to as relevance. Formally known as "page rank," Google has a process for scraping web pages to determine the link structure based broadly around the number of inbound links it receives (i.e., how many people click on it). These processes effectively "create a map" of the web that is stored inside enormous databases linking together pages to keywords to URLs - simply put, without being indexed, a page is unrecognizable to the search engine (Introna and Nissenbaum, 2000). Nonetheless, the system for returning relevant content is gameable (Gillespie, 2017). Data voids (Golebiewski and boyd, 2019) are perfect for ideological, economic, and/or political manipulators because they do not have to try and bury existing content. When little to no content exists, the "most relevant" information for a query connected to a data void is easy to replace with low quality, conspiratorial, extremist, hate-orientated, terroristic, graphic, or illicit content.

\section{Method}

This paper draws on content analysis of three cases of misinformation popularized by the right-wing media ecosystem (Benkler et. al. 2018) from 2019-2021. Case one focuses on the alleged name of the Ukrainian whistleblower at the center of former President Trump's first impeachment trial. The RWME leveraged the supposed whistleblower identity to argue that the allegations against Trump were illegitimate and distract from his wrongdoings. The second case demonstrates how a key node in the RWME (one of the founders of The Federalist) leveraged Twitter affordances to "prove" that Big Tech is silencing conservatism. The third case sheds light on how right-wing YouTube personalities tag their content with Rep. Ocasio-Cortez' Twitter handle (AOC) to spread conspiracies about the "radical left." By relying on qualitative content analysis 
(Altheide, 2000) and scraped metadata, the paper identifies how manipulators understand the nuances of media literacy while exploiting technological affordances to ensure their content will dominate search engine returns. Examining the underlying meanings, patterns and processes behind these cases sheds new light on how the framework of media literacy is currently exploited in successful media manipulation campaigns.

\section{References}

Altheide, D. L. (2000). Tracking discourse and qualitative document analysis. Poetics, 27(4), 287-299.

Anderson, C. W. (2020). Fake news is not a virus: On platforms and their effects. Communication Theory.

Benkler, Y., Faris, R., \& Roberts, H. (2018). Network propaganda: Manipulation, disinformation, and radicalization in American politics. Oxford University Press.

Bucher, T. (2017). The algorithmic imaginary: Exploring the ordinary affects of Facebook algorithms. Information, Communication \& Society, 20(1), 30-44.

Bucher, T. and Helmond, A. (2017). The affordances of social media platforms, in: J. Burgess (Ed.), SAGE Handbook of Social Media, SAGE Publications, London, 233-253.

Gillespie, Tarleton (2017) Algorithmically recognizable: Santorum's Google problem, and Google's Santorum problem, Information, Communication \& Society, 20:1, 63-80

Golebiewski, M. and boyd, d. (2019, October 29). Data Voids. Data \& Society; Data \& Society Research Institute. https://datasociety.net/library/data-voids/

Haider, J. and Sundin, O. (2019). Invisible search and online search engines. Routledge.

Introna, L.D. and Nissenbaum, H (2000). Shaping the web: Why the politics of search engines matters. The Information Society, 16(3), 169-185.

Lazer, D. M. J., Baum, M. A., Benkler, Y., Berinsky, A. J., Greenhill, K. M., Menczer, F., Metzger, M. J., Nyhan, B., Pennycook, G., Rothschild, D., Schudson, M., Sloman, S. A., Sunstein, C. R., Thorson, E. A., Watts, D. J., \& Zittrain, J. L. (2018). The science of fake news. Science, 359(6380), 1094-1096.

Marwick, A. E. (2018). Why do people share fake news? A sociotechnical model of media effects. Georgetown Law Technology Review, 474.

Schultheiss, S. \& Lewandowski, D. (2021). Misplaced trust? The relationship between trust, ability to identify commercially influenced results, and search engine preference. https://arxiv.org/abs/2101.09159 
Tripodi, F. (2017). Yakking about college life: Examining the role of anonymous forums on community identity formation, in: T. McMillan Cottom, J. Daniels, and K. Gregory (Eds.) Digital Sociologies. Policy Press.

Tripodi, F. (2018, May 16). Searching for Alternative Facts. Data \& Society; Data \& Society Research Institute.

Vaidhyanathan, S. (2012). The Googlization of Everything. University of California Press

Wardle, C., Derakhshan, H. (2017). Information disorder: Toward an interdisciplinary framework for research and policy making. Council of Europe policy report DGI(2017)09.

https://rm.coe.int/information-disorder-toward-an-interdisciplinary-framework-for-researc $1168076277 \mathrm{c}$ 


\title{
AOIR
}

Selected Papers of \#AoIR2020:

The 22nd Annual Conference of the

Association of Internet Researchers

Philadelphia, PA, USA / 13-16 Oct 2021

\section{ANAGRAMMATICAL (DIGITAL) BLACKNESS: BLACK TWITTER, SIGNIFYIN', AND THE MUNDANE}

\author{
Vincente Perez (PhD Candidate, TDPS, UC Berkeley)
}

\section{Theoretical Overview:}

Black Twitter users often engage in a critical praxis of "signifyin"' (Gates, 1983; Brock 2012), which represents a significant staple in Black technoculture. In this paper, I argue that signyfyin' represents what Black feminist scholar Christina Sharpe (2016) calls an "anagrammatical" praxis, wherein Black Twitter users engage in public digital discourse in a simultaneously mundane and critical manner. This praxis has three primary features: hacking virality, covert publicity, and Black vernacular signifyin', which constitute a multifaceted strategy of making sense of the incomprehensible nature of antiblackness. These strategies are adapted in the face of racial stereotyping, double-consciousness, and the ubiquitous grammar of antiblackness in civil (digital) society. In this paper, I mobilize a Critical Technocultural Discourse Analysis (CTDA) methodology to explore the ways in which Black Twitter users engage in a form of digital anagrammatical Blackness that reveals many of the antiblack assumptions within media literacy and gestures towards an alternative register of literacy (Brock, 2020). This alternative register rejects antiblackness and instead revels in the Black Mundane to encourage a strategic imagination of community and Black variances that speak, mobilize, and exist Otherwise (Crawley, 2016; Silva, 2020).

\section{Hacking Virality (Stereotyping/Double-Consciousness):}

Virality emphasizes a post's metrics; however, this notion of virality can produce a reductive conception of Blackness that is dematerialized and deracialized (Roth-Gordon, Harris, \& Zamora, 2020). For example, if Blackness can be appropriated to the extent that it is rendered popular and thus, fully integrated into the American Suggested citation (APA): Perez, Vincente. Anagrammatical (Digital) Blackness: Black Twitter, Signifyin', and the Mundane. Panel presented at AolR 2021: The 22nd Annual Conference of the Association of Internet Researchers. Virtual event: AoIR. Retrieved from http://spir.aoir.org. 
popular discourse, then Blackness is no longer a uniquely Black experience (Peoples, 2020). In other words, any twitter user can simply create viral content that is "Black" regardless of the racial identity of the user.

I argue that virality in the context of digital twitter usage is an antiblack process that is founded on the reductive notion that Blackness can be deracialized, dematerialized, and otherwise disaggregated from Black people. Hacking Virality gestures towards a process that sees Black digital praxis as a public performance that re/appropriates the inherent antiblack notions of a reductive blackness and instead engages in a critical form of discursive racial identity performance (@ayakamina, @itskeyon). Hacking Virality allows Black twitter users to undo and escape the logic of capture and appropriation that underlies the illusion of a completely commodifiable form of Blackness (@queering). Hacking Virality allows us to think through the way that Black twitter users interact with oppressive structures without being completely subsumed and consumed by them (Sharpe, 2016).

\section{Covert Publicity (anti-Surveillance).}

On Twitter, the normal user is imagineered as white and this translates to whiteness being billed as the de facto online persona. This persona is rendered a technocultural norm, which impacts "normal" technological use (Brock, 2020). Black Twitter is able to mobilize and dissipate because it operates through an interdependent notion of dispersed Blackness that preempts the logic of capture, objectification, and appropriation (Brock, 2020). This interdependence is forged through an intentional engagement with antiblackness and provides a backdrop to explore how civil digital society constructs itself via antiblack logics and the desires of capital (Brock 2020). To situate itself against surveillance and antiblackness, this praxis must occur publicly, but in a way encourages experiences that can't be wholly captured (Browne, 2015).

\section{Signifyin' (Anagrammatical praxis)}

Black Twitter users fight back against the appropriation of African American Vernacular English (AAVE) through the use of anagrammatical praxis of Signifyin' (@queeringpsych, @romdresss). Black Signifyin' hacks virality to engage in a public performance of Blackness that is discursive rather than merely "clever" (Brock, 2020:109-110). A Black digital praxis that is anagrammatical re/codes the logic of virality away from objectification and towards a revealing of difference that creates an optical and sonic experience of a Blackness turned inward, a distributed Blackness. Although the libidinal economy must be interfaced with it cannot fully subjugate Blackness.

\section{Methodology: Critical Technocultural Discourse Analysis}


My methodology is heavily informed by Brock's mobilization of CTDA as "a critical analysis of the ways that people manage technological constraints on action, agency, and being" (2020: 9). This multifaceted approach provides the opportunity to 1: isolate the ideology that informs the technological artifact, 2: examine the technocultural praxis associated with the artifact, and 3: analyze the discourses that emerge from its users (Brock 2020). In other words, analysing Twitter, Black Signfyin' on Twitter, and Black Twitter discourses simultaneously creates a more revealing picture of the creativity, play, and desires within Anagrammatical Black digital praxis. This moves us away from the terms of agency and resistance, which opens up the potential for a more radical imagination of not only what is actually happening within Anagrammatical (Digital) Blackness, but also, what futures, presents, and pasts are opened up when connections are forged through different pathways (Sharpe, 2016; Ferreira Da Silva, 2020).

\section{Intraspection as Interdependence}

These anagrammatical practices are radical because they create an alternative digital landscape where Black people, when turned inwards/towards Blackness, can reject antiblackness and its ideological underpinnings (Sexton, 2011). This communal praxis happens in real time and cannot easily be appropriated or objectified. This slippery and adaptive strategy is informed by a notion of what I call "Intra-spection," that creates a sense of Black interdependence.

This is a form of literacy that belies the notion of the literate and creates a radical potential in the mundane, illegible, and imperceptible (Silva 2020). What freedom/s exist when we turn away from perception and surveillance and revel in the opaque and a notion of "we" that is defined not by an objectifying notion of unity, but rather by its differences and variances (Ibid)? Civil digital society promotes a sense of digital literacy that attempts to present a race-less conception of commonly accepted appropriate technology use (Brock, 2020, @itskeyon). This has resulted in a conceptualization of the technocultural sphere as a cultural free for all, which depoliticizes Black cultural praxis and renders it available for complete appropriation. Black digital praxis counters this antiblack notion by negotiating the stakes of public discourse around proper technological use.

\section{References}

Alhabash, S., Quilliam, E. T., McAlister, A. R., Lou, C., \& Richards, J. I. (2014). Is it me or is it just virality? American Academy of Advertising. Conference Proceedings (Online) (p. 13) 
Brock, A. L. (2020). Distributed Blackness: African American cybercultures.

Brock, A. (2012). From the blackhand side: Twitter as a cultural conversation. Journal of Broadcasting \& Electronic Media, 56(4), 529-549.

Browne, S. (2015). Dark matters: On the surveillance of blackness.

Crawley, A. T. (2016). Blackpentecostal breath: The aesthetics of possibility. Fordham Univ Press.

Ferreira Da Silva, Denise. King, T. L., In Navarro, J., \& In Smith, A. (2020). "Reading the dead" Otherwise worlds: Against settler colonialism and anti-Blackness. 38-51

Gates, H. L. 1983. The blackness of Blackness: A critique of the sign and the signifying monkey. Critical Inquiry, 9(4): 685-723.

Peoples, Gabriel A. (2020) The forgotten Kelly Dodson. Women \& Performance: a journal of feminist theory, 30:2, 170-194

Roth-Gordon, J., Harris, J., \& Zamora, S. (2020). Producing white comfort through "corporate cool" International Journal of the Sociology of Language, 2020(265), 107-128.

Sexton, J. (2011). "The social life of social death." InTensions, 5(1), 1-47.

Sharpe, C. (2016). In the wake: On blackness and being. Duke University Press.

Tweets:

Lani. [@ayakaminaj] "nonblacks please be aware that sus is a slur. back during slavery, white slave masters would call suspected runaway slaves sus and they would be wh*pped in retaliation. please be mindful :l". Twitter. March 162021 https://twitter.com/ayakaminaj/status/1371814941691424769

Care, Muting/Blocking = Self.[@QueeringPsych] Stop Translating AAVE For Non-Black Ppl. If They Don't Understand, It's Not Meant for Them to Know Teach a New Word \& They'll Disrespectfully Use It out of Context, Make \$ off It, \& Then "Cancel" It When They Get Boredl Get Annoyed Seeing Y'all Perform Free THANKLESS Labor. Twitter, 16 Mar. 2021, twitter.com/QueeringPsych/status/1371727524292595717.

HOOD VOGUE is tired of poverty. [@itskeyon]Y'all Will Pay for Ur Crimes for Making Mainstream Media Think Aave Is Just "Gen-z Language" Pic.twitter.com/teydl8kx9r. Twitter, 9 May 2021, twitter.com/itskeyon/status/1391433136760893440.

Edxn. [@romdresss] "Periodt Purr Sis Deadass Pooh Chile!! ...Girl What." Twitter, Twitter, 9 May 2021, twitter.com/romdresss/status/1391448816033964040. 
nonblacks please be aware that sus is a slur. back during slavery, white slave masters would call suspected runaway slaves sus and they would be wh*pped in retaliation. please be mindful :/

6:25 AM $\cdot 3 / 16 / 21 \cdot$ Twitter for iPhone

29 Retweets 11 Quote Tweets 230 Likes

七』 0 个

饣】 hmm? Retweeted

Muting/Blocking $=$ Self Care $\cdot 16 \mathrm{~m}$

Stop translating AAVE for non-Black ppl.

If they don't understand, it's not meant for them to know

Teach a new word \& they'll disrespectfully use it out of context, make \$ off it, \& then "cancel" it when they get bored

I get annoyed seeing y'all perform free thankless labor

セ】13 ○37 个

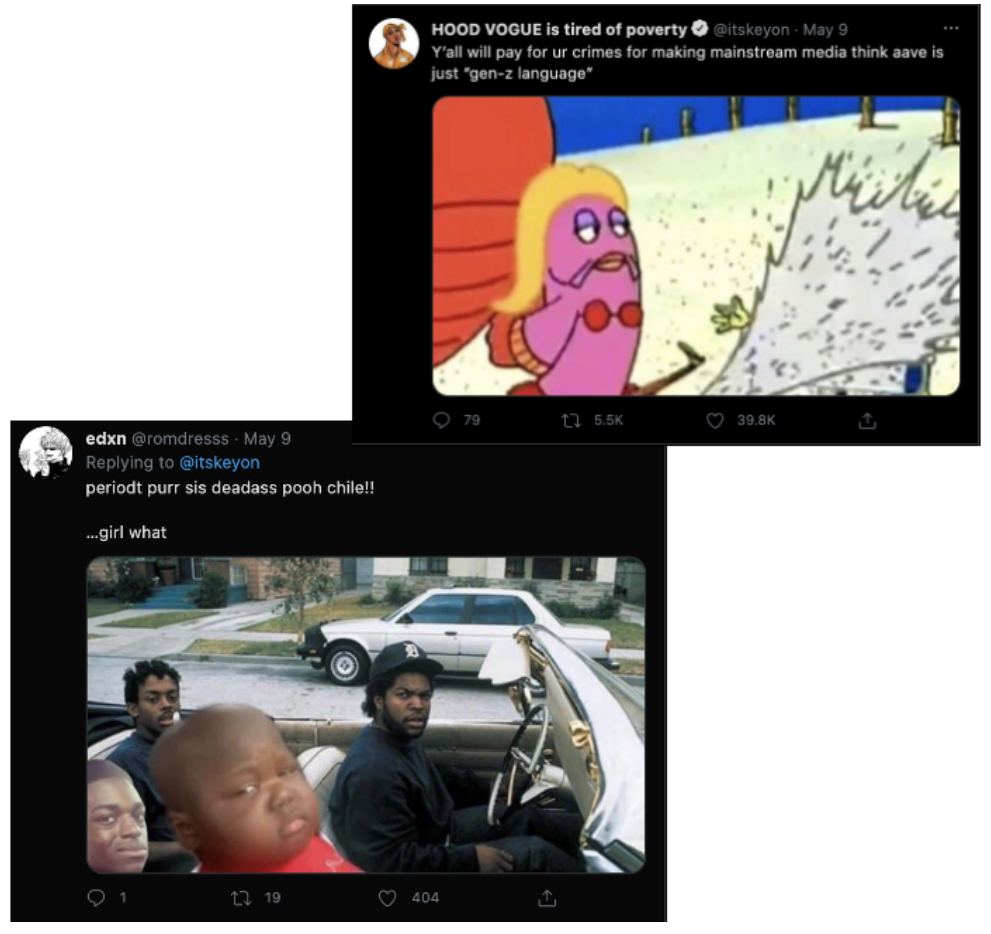

